\title{
The Evaluation of Iranian EFL Textbooks from Post Method Principles Pedagogy
}

\author{
Yalda Hooman \\ Department of English, Sistan and Baluechstan Science and Research Branch, Islamic Azad University, Zahedan, Iran
}

\begin{abstract}
EFL materials and textbooks are important factors in many language programs and making judgments about their needs meticulous book evaluation. In Iran, different textbooks are used for teaching general and technical English to undergraduate students at universities. Despite the great use of these textbooks and dominance of post method in EFL classrooms, it is not yet known to what extent the principles of particularity, possibility, and practicality are observed in the currently practiced EFL textbooks at Iranian universities. The main objectives of the presents study were to investigate whether the principles of post method have been applied in these textbooks or not. The data of the present were collected through a researcher developed instrument. This instrument, book evaluation consists of ten items measured on a five point Liker scale. The participants were selected from two different groups: EFL teachers and EFL learners at all universities in Sistan and Baluchistan province. The data were analyzed using T-Test. The results of the study indicated that both learners and teachers believed that the current textbooks are not against the learners' ethnicity, gender, and cultural values. However, they argued that the other principles were not given appropriate attention.
\end{abstract}

Index Terms - EFL textbook evaluation, post method

\section{INTRODUCTION}

It is a deed doubt that English has become the core of communication in the world. EFL materials and textbooks are key factors in many language programs and making judgments about them needs book evaluation. The main objectives of the presents study were investigate whether the principles of post method have been applied in these textbooks or not.

\section{REVIEW OF LITERATURE}

\section{A. Textbook Evaluation}

English Language is the lingua franca of modern world. According to (Dubin\& Olshtain, 1986), suggest that the textbook is tangible element for teachers and learners to gives a face validity to a language course. Further, Hutchinson and Torres (1994) declare that suitable textbook is the best means to have long- lasting changes. Regarding the multiple roles of textbooks in EFT, Razmjoo (2007) propose that students working with a textbook have a sense of progress, security and achievement. Besides, Cuuingsworth (1995) suggests that textbooks are an effective source for presenting materials by the teachers, a useful source for self-directed learning, a reference source for students, a source of ideas and activities, a syllabus that reflects prescribed learning objectives, and support for few skillful teachers who have yet to gain in confidence. Regarding the advantages, there are many strategies available about book evaluation and many scholars work on it. Such as (Hutchinson \& Waters, 1996; Cunningsworth, 1984; Chambers, 1997; Littelejohn, 1996; McDonough \& Shaw, 1993; Breen \& Candlin, 1987; Shelden, 1988 ; Tucker, C. A., 1975; Mathews, 1985; Ur, 1996; Skierso, 1991).

\section{B. Current Approaches to Materials Evaluation in ELT}

Evaluation is a familiar term in the realm of education. Every educational system has five important parameters (a teacher, students, teaching methods, materials, and evaluation). As (Tarone \& Yule, 1989) argue freedom of making decisions is ignored if learners' needs just mentioned without awareness of prescribed textbooks that is staple in EFL classes. According to Germaine and Rea-Dickens (1992), argue that evaluation is related to learning process in one way and to development and teacher changes in another way. Furthermore, Kiely (2009) discuss that evaluation is pivotal role to ensure enhancement and quality assurance.

Similarity, Jones (1999) declares that evaluation has root in theoretical and empirical determination of curriculum and its details from various perspectives, consideration of teacher's performance, learner's accomplishment, and materials. Additionally, Yumuk (1998) defines evaluation as an "interactive process " that includes a deep assessment of the used materials. In another definition, he emphasizes on integral relation between teachers, learners and materials.

As Tomlinson (2001) argues that textbook evaluation is an applied linguistic activity through that supervisors, teachers, materials developers, and administrators can make judgments about the benefit of the materials for the people using them. Additionally, Ellis (1997) and Cunningsworth (1995) propose that textbook evaluation helps teachers act beyond impressionistic assessments. 
In this regards, Ellis (1997) defines two kinds of evaluation, namely, predictive and. retrospective The former relates to what materials are suitable to learners 'needs and latter definition regards to whether that materials have applied or not. Moreover, he adds that teachers have two principles for predictive evaluation. One is depends on expert reviewers' attitude who distinguish specific criteria for material evaluation.

\section{Models for Material Evaluation}

As regarding two approaches in material evaluation, model evaluation can be in line with Macro and Micro evaluation. At this view, Grant (1987) suggests a three-stage process for material evaluation. At the first, initial evaluation that is related to appearance of the book without scrutinizing in details .At the next, detailed evaluation that is related to the effectiveness of the course for learners, teachers and syllabus. Finally, in-use evaluation re-evaluates the specific material durably.

In line with Grant (1987), McDonough and Shaw (1993) show a three- stage evaluation .External evaluation that refers to overall view of the material from the outside. Second stage, internal evaluation that is related to investigate materials deeply. At the last, Overall evaluation that is refers to some factors such as suitability, generalizability, flexibility and adaptability in materials. In regards to material evaluation model, Breen and Candlin (1987) suggest a two- phase evaluation. The first phase consists of some initial question to see the effectiveness of materials and second phase relates to that first question in phase one that are the best and the closest to choose and use materials for specific group. However, all of these models focus on define, choose, advance criteria that the best serve the goal of the assessment aimed at (Breen and Candlin, 1987; Hutchinson, 1997; Grant, 1987; McDonough and Shaw, 1993; Ellis, 1997; Yumuk, 1998).

\section{Criteria for Material Evaluation}

A large and growing body of literature has investigated about materials evaluation. Therefore, various evaluation criteria suggested by many scholars. Regardless of the learning and teaching situation, criteria proposed by scholars for material evaluation order a checklist or guideline to better understanding. However, far too little attention has been paid to select reliable criteria. According to Sheldon (1988), nobody knows what criteria are applicable in ELT text, content, and worldwide.

\section{Evaluating the Sketch and the Figure:}

A number of scholars such as (Sheldon, 1988; McDonough\&Shaw, 1993; Cunningsworth, 1995) emphasize on the practicality of the textbook package price as an elementary option to choose and evaluate textbook. To start with, (Daoud \& Celce- Murica, 1979) declare that physical figure of the textbook can be analyze in line with cover durability and the attractiveness of the textbook parameters such as cover, form, page and binding. In another way, it is important to estimate weight and size of the textbook for learners to handle it (Sheldon, 1988; Mc Donough \& Shaw, 1997).

\section{Evaluating the Skills and the Sub-Skill:}

In line with the methodologies in language teaching, in previous decades, authors just had been accepted GTM (grammar translation method) or ALM (audio-lingual method).Recently, there has been critical and dynamic change since 1980s. In this view, some approaches get important to write textbooks as CB (content- Based), TB (task- based), or skill-based.All of them emphasize on the language skills following communication principles. According to Breen \& Candlin (1987), three aspect mention to evaluate skill and sub-skill. The firs aspect is to find skills in materials and next aspect is the proportion of each skill in the course period, and last aspect, whether the first purposes are followed or not.

\section{Evaluating the cultural components:}

In term of cultural view, as Alptekin (1993) declares similarity between L1\&L2 is a facilitator of learning. In another way, target culture should be taught in a way that fills the gap among two languages. Similarity, Cunnigworth (1995) states that cultural and social factors made learning better. Moreover, he adds the characteristic of textbook is a staple of the cultural of society. In this view, Sheldon (1988) emphasize on the assessment in ELT materials based on cultural bias.

\section{E. Transition from Method to Post Method}

As this regards, Okazaki (2005) based on recent research on SLA discusses that classroom are far from social and historical conditions. Furthermore, (Norton \& Toohey, 2004; Pennycook, 1991, 2001; Ramanathan, 2002; Canarajah, 1999, 2001; Morgan 1998; Benesch, 2001) suggest critical pedagogy or an alternative approach should be the heart of language teaching. Moreover, Vandrick (1994) points out that the main aim of critical pedagogy to educate all people regardless of their class, race, and gender.

In the early of twentieth century, the EFL practitioners and researcher argued to realize that no single approach and method would be the vital frame work to bring success in teaching a foreign language. They used critical pedagogy as a cornerstone of new method which is called post method .Brown (2007) defines it a rational for language teaching and learning and Kumaravadivelu (2006) explains approach as theoretical principles governing language teaching and learning.Post method pedagogy helps us to go beyond and overcome the limitation of methods. As kumaravadivelu (2003) emphasizes the consequences of post method are three features; particularity, possibility and practicality.

\section{Macro strategic framework}


As Kumaravadivelu (2006) states Macro strategic framework was defined from theoretical empirical and experimental knowledge. As Kumaravadivelu (1994) mentions this way gives teachers meaningful guidelines based on which they simultaneously will be aware of teaching process and be able to proof it.

2. Kumaravadivelu's 10 Macro strategies for language teaching:

1. Maximizing learning opportunities:

2. Minimizing perceptual Mismatches

3. Facilitating Negotiated Interaction

4. Prompting Learner Autonomy

5. Foster Language Awareness

6. Activating Intuitive Heuristics

7. Contextualizing Linguistic Input

8. Integrating Language Skills

9. Ensuring Social Relevance

10. Raising Cultural Consciousness

Despite the great use of these textbooks and dominance of post method in EFL classrooms, it is not yet known to what extent the principles of particularity, possibility, and practicality are observed in the currently practiced EFL textbooks at Iranian universities.

\section{Methodology}

\section{A. Participants}

The participants were selected from two different groups: EFL teachers and EFL learners. EFL teachers were selected from all EFL teachers at all universities in Sistan and Baluchistan province. 42 EFL instructors were selected through convenience sampling. The criterion for recruiting teachers in the study was teaching experience at the universities at least for three semesters.

The next group of the participants consisted of 150 undergraduate students from different fields of the study at the mentioned universities. The participants were selected through multistage sampling. That is, at first from all university one or two universities were randomly selected. Then, from each university 10 departments were randomly selected. Next, from each department one major was selected. Finally, from each field of study, the students who were volunteer to take part in the study were selected through convenience sampling. The criterion for selecting the participants was either passing English course or taking it within the present term. The final number of the students who voluntarily took part in the study was 150 . For the sake of ethical considerations, all the participants were informed about the purpose of the study. They were also allowed to withdraw from the study anytime they liked.

\section{B. Instrumentation}

The data of the present were collected through a researcher developed instrument. This instrument, book evaluation consists of ten items measured on a five point Liker scale. In line with the meanings of the items as well as the 10 principles of post method, the instrument was divided to 10 dimensions. Then, the content validity of the present scale was approved by three applied linguists, faculty members of state universities in Zahedan and Tehran. The construct validity was estimated through confirmatory factor analysis. That is, factor analysis was run for all dimensions of the instrument. the reliability of the instrument was estimated through cronbach alpha for the total instrument and all 10 dimensions separately. The reliability index for the whole instrument and its dimensions exceeded 10 which are all acceptable.

\section{Procedures}

Upon arrival, the data collection was scheduled to be conducted in autumn, 2013 in Zahedan, Iran. The administration of the survey continued 30 minutes each section. The completely attempted questionnaires were coded and entered into SPSS. (version 16). The data of the study were analyzed through running descriptive and inferential statistics. The mean and standard deviation of each person on all dimensions of the instrument as well as all items of the instrument are calculated. One sample t-test for all dimensions was also run to compare the means of the sample and population. In addition, independent sample t-test was run to compare the means of teachers and learners.

The reliability coefficient of the factors, which forms part of the book evaluation dimension, appeared to vary between 0.75 and 0.88 which could be regarded as acceptable internal consistency (Kline, 1999). Therefore, it could be strongly argued that the data gathered from the students and the teachers had acceptable internal consistency. 
TABLE 1.

RELIABILITY ANALYSIS OF THE SCALE

\begin{tabular}{|l|l|l|}
\hline Variable & group & Cronbach alpha \\
\hline Maximizing learning opportunities & teacher & .8 \\
\hline & student & .75 \\
\hline Minimizing perceptual mismatches & teacher & .82 \\
\hline Facilitating negotiated interaction & student & .76 \\
\hline Promoting learner autonomy & teacher & .88 \\
\hline \multirow{2}{*}{ Fostering language awareness } & student & .8 \\
\hline Activating intuitive heuristics & teacher & .75 \\
\hline Contextualizing linguistic input & student & .76 \\
\hline Integrating language skills & teacher & .82 \\
\hline & student & .80 \\
\hline Ensuring social relevance & teacher & .86 \\
\hline Raising cultural consciousness & student & .84 \\
\hline Total score & teacher & .78 \\
\hline & student & .8 \\
\hline & teacher & .81 \\
\hline & student & .82 \\
\hline & teacher & .85 \\
\hline & student & .75 \\
\hline & teacher & .86 \\
\hline & student & .76 \\
\hline & teacher & .81 \\
\hline student & .78 \\
\hline & & \\
\hline
\end{tabular}

The reliability coefficient of the factors, which forms part of the book evaluation dimension, appeared to vary between 0.75 and 0.88 which could be regarded as acceptable internal consistency (Kline, 1999). Therefore, it could be strongly argued that the data gathered from the students and the teachers had acceptable internal consistency.

\section{THE RESEARCH FIRST QUESTION}

Q1- To what extent Iranian EFL textbooks are prepared by principle of post-Method?

In the following table, teachers' means and mean ranks on all dimensions are represented.

TABLE 2.

TEACHERS' MEANS ON MEAN RANKS ON ALL DIMENSIONS OF THE SCALE

\begin{tabular}{|l|l|l|}
\hline Principles & Mean & Mean ranks \\
\hline Maximizing learning opportunities & 2.7698 & 7.61 \\
Minimizing perceptual mismatches & 2.0317 & 3.88 \\
Facilitating negotiated interaction & 2.9365 & 7.99 \\
Promoting learner autonomy & 2.3413 & 5.46 \\
Fostering language awareness & 1.9603 & 3.36 \\
Activating intuitive heuristics & 2.2143 & 3.52 \\
Contextualizing linguistic input & 2.5619 & 6.49 \\
Integrating language skills & 2.0952 & 3.94 \\
Ensuring social relevance & 3.6310 & 9.74 \\
Raising cultural consciousness & 1.9286 & 3.01 \\
Valid N (listwise) & & \\
\hline
\end{tabular}

The results in the above table show that the mean scores of the teachers on the dimension of ensuring social relevance is 3.63 which falls above the cutoff point. The results also show that the teachers scores on the other dimensions of book evaluation scale fall below the cutoff point. Their mean scores on the next two dimensions "Facilitating negotiated interaction" and maximizing learning opportunities are 2.93 and 2, 76, respectively which are a little bit above the median (2.5).

Generally speaking, it seems to Iranian university EFL teachers have a positive perception about the ensuring social relevance dimension of the book evaluation scale. Their perceptions about the other dimensions tend to be either neutral or negative.

TABLE 3

FRIEDMAN TEST FOR TEACHERS' ATTITUDES TO PRINCIPLES OF POST METHOD

\begin{tabular}{|l|l|}
\hline $\mathbf{N}$ & 42 \\
\hline Chi-Square & 231.376 \\
\hline df & 9 \\
\hline Asymp. Sig. & .001 \\
\hline a. Friedman Test & \\
\hline
\end{tabular}


The table shows the results of Friedman test and the mean of post-method variables and the researcher has used it to clarify the degree to which the variables of above mentioned method have been observed in the universities' EFL textbooks. Results show that from teachers' points of view, the dimensions of the book evaluation from post method perspectives can be ranked as follows:

1- Ensuring social relevance

2- Facilitating negotiated interaction

3- Maximizing learning opportunities

4- Contextualizing linguistic input

5- Promoting learner autonomy

6 -Integrating language skills

7- Minimizing perceptual mismatches

8- Activating intuitive heuristics

9- Fostering language awareness

10- Raising cultural consciousness

Also, from Chi-Square text $(\mathrm{X} 2=231, \mathrm{df}=9, \mathrm{p}=0.001<0.05)$, it can be concluded that the above mentioned test is statistically significant and with a 99 percent certainty, it can be said that the post method has been applied in university textbooks and from professors and students' point of view it has been effective. Therefore, it could be strongly argued that in the reviewed textbooks, students' awareness of cultural differences was given the least attention by the textbook developers.

Learners' means and mean ranks on all dimensions of the scale

In the following table, 1; earners' means on all dimensions are represented.

TABLE 4.

LEARNERS' MEANS AND MEAN RANKS ON PRINCIPLES OF POST METHOD PEDAGOGY

\begin{tabular}{|l|l|l|}
\hline Principles & Mean & Mean ranks \\
\hline Maximizing learning opportunities & 2.04 & 3.76 \\
Minimizing perceptual mismatches & 2.1 & 4.01 \\
Facilitating negotiated interaction & 2.25 & 5.72 \\
Promoting learner autonomy & 2.17 & 5.53 \\
Fostering language awareness & 2.3 & 6.30 \\
Activating intuitive heuristics & 2.2 & 4.06 \\
Contextualizing linguistic input & 2.12 & 4.32 \\
Integrating language skills & 2.00 & 3.84 \\
Ensuring social relevance & $\mathbf{3 . 1 2}$ & 8.61 \\
Arising cultural consciousness & 2.3 & 8.85 \\
Chi-square & 23.17 & \\
Sig. & 0.001 & \\
\hline
\end{tabular}

The results in the above table show that the mean scores of the learners on the dimension of ensuring social relevance is 3.12 which falls above the cutoff point. The results also show that the learners scores on the other dimensions of book evaluation scale fall below the cutoff point. Generally speaking, it seems to Iranian university EFL learners have a positive perception about the ensuring social relevance dimension of the book evaluation scale. Their perceptions about the other dimensions tend to be negative.

Also, from Chi-Square text $\left(\mathrm{X}^{2}=23.7, \mathrm{df}=9, \mathrm{p}=0.001<0.05\right)$, it can be concluded that the above mentioned test is statistically significant and with a $99 \%$ certainty, it can be said that the post method has been applied in university textbooks and from professors and students' point of view it has been effective.

\section{The RESEARCH SECOND QUESTION}

Is there any difference between the evaluations conducted by EFL teachers and EFL learners?

TABLE 4.8.1

THE RESULT OF INDEPENDENT T- TEST CONCERNING THE POST METHOD APPLICATION BASED ON GROUPS

\begin{tabular}{|c|c|c|c|c|}
\hline Principles & $\begin{array}{l}\text { Mean } \\
\text { learners }\end{array}$ & teachers & $t$ & sig \\
\hline $\begin{array}{l}\text { Maximizing learning opportunities } \\
\text { Minimizing perceptual mismatches } \\
\text { Facilitating negotiated interaction } \\
\text { Promoting learner autonomy } \\
\text { Fostering language awareness } \\
\text { Activating intuitive heuristics } \\
\text { Contextualizing linguistic input } \\
\text { Integrating language skills } \\
\text { Ensuring social relevance } \\
\text { Raising cultural consciousness }\end{array}$ & $\begin{array}{l}2.04 \\
2.1 \\
2.25 \\
2.17 \\
2.3 \\
2.2 \\
2.12 \\
2.00 \\
3.12 \\
2.3\end{array}$ & \begin{tabular}{|l|}
2.76 \\
2.03 \\
2.93 \\
2.34 \\
1.96 \\
2.21 \\
2.56 \\
2.52 \\
3.63 \\
1.92
\end{tabular} & $\begin{array}{l}77 \\
87 \\
.97 \\
.82 \\
1.1 \\
4 \\
-1 \\
.4 \\
1.3 \\
.5\end{array}$ & $\begin{array}{l}0.4 \\
0.3 \\
0.27 \\
0.29 \\
0.3 \\
0.25 \\
0.6 \\
0.4 \\
0.21 \\
0.12\end{array}$ \\
\hline
\end{tabular}


The results in the above table show that there is no significant difference between learners and teachers perceptions about the application of the principles of post-method in the EFL textbooks used at Iranian universities. Therefore, the null hypothesis was rejected $(\mathrm{p}>0.05)$.

\section{Discussion AND PEDAGOGICAL IMPLICATION}

The findings of this study raise a number of important issues regarding the EFL textbook evaluations. First, since the textbook are used for university students, the topics should be rearranged or chosen by taking into consideration their ages, expectations, and needs. Second, the illustrations may be restructured to meet the expectations of university students by providing high-quality standards similar to the ones proposed by the tenants of post method.

Third, from the teachers' perspectives, the teacher's guide can be revised in order to provide practical ideas for the teachers to use in the classroom. Fourth, the results are considered to be informative considering the textbook elements which do not require revision regarding teachers' and students' textbook evaluation results such as the social relevance principle which was not violated the textbook developers. Fifth, the textbook developers should take into account the findings a revise the textbooks through cooperation with experts such as applied linguists and education experts. Finally, the students should know the use of the only introduced textbooks by the teachers cannot solve their language learning problems.

\section{CONCLUSIONS}

In line with results of the study the following conclusions were made:

1-Textbook exercises were provided for learner with different learning strategy preferences.

2-The books are not accompanied by supplementary materials such as Videos, slides, photocopies, CD and etc.

3- Undergraduate students and EFL teachers have not been involved in the process of material development.

4-University EFL textbooks do not promote critical thinking among teachers and learners.

5- The textbooks do not promote interaction between teachers and learners.

6-Learners with different language background cannot benefit from the textbooks.

7-There are no appropriate activities to help students develop intellectually.

8-The contents of textbooks are not designed in line with attempt to draw learner's attention to formal and functional properties of their second language learning

9-The instructional activities of the textbook do not promote learners' creativity.

10- Authentic and real life materials were not used in the textbook.

11-They do not promote learners' responsibilities as the agents of social changes.

12-The current textbooks are not against the learners' ethnicity, gender, and cultural values

\section{LIMITATIONS OF THE STUDY}

Like the other survey studies, the present had some limitations. Due to the time limitation, only the English textbooks which were taught as general English courses were selected. Therefore, the results are context dependent and they should be generalized with great care. The other limitation was that the participants were not selected through random sampling. The last limitation of the study was students problems in understanding the English version of the instrument, therefore, the research had to provide them with Persian version of the instrument which might not have had crosstranslation reliability.

\section{RECOMMENDATIONS FOR FURTHER STUDIES}

The other researchers can replicate the present study using a representative sample of participants from all universities in Iran. Moreover, this study selected participants from all fields of study, as the results might be different across different fields of study; the other participants are recommended to take into account the variable of academic disciplines or fields in the other studies. The other researchers are also recommended to evaluate the textbooks used at Iranian universities with those in English speaking countries. The last but not the least, the other researchers are recommended to evaluate the English textbooks designed by local and non-local applied linguists.

\section{REFERENCES}

[1] Alptekin, C. (1993). Target-language culture in EFL materials. ELT Journal [47, 136-143]

[2] Benesch, S. (2001). Critical English for academic purposes: Theory, politics, and practice. Mahwah, NJ: Erlbaum.

[3] Breen, M. \& C. Candlin (1987). Which materials? A consumer's and designer's guide. In L. E. Sheldon (ed.), ELT textbooks and materials: Problems in evaluation and development. ELT Documents 126. London: Modern English Publications and the British Council.

[4] Brown, H.D. (2002). English language teaching in the "post-method" era: Toward better diagnosis, treatment and assessment," in Richards, J. C. and W. A. Renandya, (Eds.), Methodology in Language Teaching (pp. 9-18). United Kingdom: Cambridge University Press. 
[5] Canagarajah, A. S. (1999). Resisting linguistic imperialism in English teaching. Oxford:Oxford University Press.

[6] Canarajah, A.S. (2002). Critical academic writing and multilingual students .Ann, Arbor, MI, University of Michigan.

[7] Daoud, A. \& Celce-Murcia, M. (1979). Selecting and evaluating a textbook. In M. Celce-Murcia and L. McIntosh (Eds.), Teaching English as a second or foreign language (pp. 302-307).Cambridge, MA: Newbury House Publishers.

[8] Dubin. F. Olshtain, E. (1986). Course Design. Developing Programs and Materials for Language Learning. Cambridge: Cambridge University Press.

[9] Ellis, P. and Ellis, M. (1987). Learning by Design Criteria for ELF Course books. In L. E. Sheldon (ed.) ELT Textbooks and Materials: Problems in Evaluation and Development, (pp. 90-98). Oxford: Modern English Publications.

[10] Grant, N. (1987). Making the most of your textbook. Harlow: Longman.

[11] Hutchinson, T. \& E. Torres (1994). The textbook as agent of change. ELT Journal 48.4, 315-328.

[12] Islam, C. \& C. Mares. (2003). Adapting classroom materials. In B. Tomlinson (ed.), 86-100.

[13] Jones, L. (1985). Use of English. Cambridge: Cam-bridge University Press.

[14] Kiely R. (2009). Small answers to the big question: Learning from language program evaluation. Language Teaching Research, 13(1), 99-116.doi:10.1177/1362168808095525

[15] Kumaravadivelu, B. (1994). The post-method condition: (E) merging strategies for second/foreign language teaching. TESOL Quarterly, [28(1), 27-48]

[16] Kumaravadivelu, B. (2006). Understanding language teaching: From method to post method. Mahwah, NJ: Lawrence Erlbaum Associates.

[17] Littlejohn, A. (1992). Why are ELT Materials the way they are? Ph.D. thesis. Lancaster University. Littlejohn, A. (2011). The analysis of language teaching materials: Inside the Trojan horse. In B. Tomlinson (ed.), 179-211.

[18] McDonough, Jo. \& Shaw, C. (1993). Materials and methods in ELT. Oxford: Blackwell.Petrovitz, W. (1996). The role of context in the presentation of grammar. ELT Journal, [51-3]

[19] Pennycook, A. (2001). Critical applied linguistics: A critical introduction. Mahwah, New Jersey: Lawrence. Erlbaum Associates Publishers. Quible, Z. (2006).

[20] Pennycook, A. (1989). The concept of method, interested knowledge, and the politics of language teaching. TESOL Quarterly, 23, 589-618.

[21] Matthews, A. (1985). Choosing the best available textbook. In A.Matthews,M.Spratt\&L.Dangerfield (eds.), At the chalkface. London: Edward Arnold, 202-206.

[22] Razmjoo. (2007) .Text book evaluation and Selection in EFL context. Authenticity of Iranian English Textbookd for schoold. Atextbook Evaluation of speech ACTS and Language F unction.

[23] Rea-Dickens, P. and Germaine, K. (1994). A Study of Iranian High School English Textbooks Based on the Standard Criteria In Candlin and Widdowson(ed.), Oxford University Press.135

[24] Sheldon, L. E. (1988). Evaluating ELT textbooks and materials. ELT Journal, [42,237-246]

[25] Skierso, A. (1991). Textbook selection and evaluation. In M. Celce-Murcia (ed.), 432-453.

[26] Tomlinson, B. (2001). Materials development. In R. Carter, \& D. Nunan (Eds.), The Cambridge guide to teaching English to speakers of other languages (pp. 66-71). Cambridge, UK: Cambridge University Press.

[27] Tomlinson, B. (2003). Dec 12, 2013 - Islam, C. \& Mares, C. Adapting classroom materials. Developing materials for language teaching (pp. 86-100).

[28] Tucker, C. A. (1975). Evaluating beginning textbooks. English Teaching Forum. [13: 355-61]

[29] Tok, H. (2010). "TEFL textbook evaluation: From teachers' perspectives" Educational Research and Review, (9), pp. [508517.]

[30] Ur, P. (1996). A Course in Language Teaching: Practice and Theory. Cambridge: Cambridge University Press.

[31] Vandrick. (1994). Feminist pedagogy and ESL. College ESL., [4(2): 69-92]

[32] Yule, G., Matthis, T., \& Hopkins, M. (1992). On reporting what was said. ELT Journal, 46(3), 245-251. Volume 13 Number 2 June 2012 Rowand, C. (2000).

Yalda Hooman was born in Zahedan, Iran in 1979.She received her M.A. degree in English Teaching .from Since \& Research Branch, Islamic Azad University, Zahedan, Iran. She is currently teaching in Teaching Training Center in Zahedan, Iran. Her research interestes include Methodology, special post method and psycholinguistic. 